\title{
Improved ice loss estimate of the northwestern Greenland ice sheet
}

\author{
Kristian K. Kjeldsen, ${ }^{1}$ Shfaqat Abbas Khan, ${ }^{2}$ John Wahr, ${ }^{3}$ Niels J. Korsgaard, ${ }^{1}$ \\ Kurt H. Kjær, ${ }^{1}$ Anders A. Bjørk, ${ }^{1}$ Ruud Hurkmans, ${ }^{4}$ Michiel R. van den Broeke, ${ }^{5}$ \\ Jonathan L. Bamber, ${ }^{4}$ and Jan H. van Angelen ${ }^{5}$
}

Received 8 August 2012; revised 7 November 2012; accepted 13 November 2012.

[1] We estimate ice volume change rates in the northwest Greenland drainage basin during 2003-2009 using Ice, Cloud and land Elevation Satellite (ICESat) laser altimeter data. Elevation changes are often reported to be largest near the frontal portion of outlet glaciers. To improve the volume change estimate, we supplement the ICESat data with altimeter surveys from NASA's Airborne Topographic Mapper from 2002 to 2010 and NASA's Land, Vegetation and Ice Sensor from 2010. The Airborne data are mainly concentrated along the ice margin and thus have a significant impact on the estimate of the volume change. Our results show that adding Airborne Topographic Mapper and Land, Vegetation and Ice Sensor data to the ICESat data increases the catchment-wide estimate of ice volume loss by $11 \%$, mainly due to an improved volume loss estimate along the ice sheet margin. Furthermore, our results show a significant acceleration in mass loss at elevations above $1200 \mathrm{~m}$. Both the improved mass loss estimate along the ice sheet margin and the acceleration at higher elevations have implications for predictions of the elastic adjustment of the lithosphere caused by present-day ice mass changes. Our study shows that the use of ICESat data alone to predict elastic uplift rates biases the predicted rates by several millimeters per year at GPS locations along the northwestern coast.

Citation: Kjeldsen, K. K., S. A. Khan, J. Wahr, N. J. Korsgaard, K. H. Kjær, A. A. Bjørk, R. Hurkmans, M. R. van den Broeke, J. L. Bamber, and J. H. van Angelen (2013), Improved ice loss estimate of the northwestern Greenland ice sheet, J. Geophys. Res.: Solid Earth, 118, doi:10.1029/2012JB009684.

\section{Introduction}

[2] During the past decade, several efforts have been made to estimate Greenland ice mass balance [Rignot et al., 2008, 2011; Sasgen et al., 2012; Thomas et al., 2006; van den Broeke et al., 2009; Velicogna, 2009]. Some mass loss estimates show that mass loss rates from major parts of the ice sheet have more than doubled since the 1990s, especially in the coastal regions of southeastern and northwestern Greenland [Chen et al., 2007; Khan et al., 2010a; Luthcke et al., 2006; Pritchard et al., 2009; Velicogna and Wahr, 2006]. Given the direct impact of Greenland ice sheet (GrIS) mass loss on global sea level, the determination of current changes in the GrIS is of major importance.

\footnotetext{
${ }^{1}$ Centre for GeoGenetics, Natural History Museum, University of Copenhagen, Copenhagen, Denmark.

${ }^{2}$ DTU Space - National Space Institute, Technical University of Denmark, Department of Geodesy, Kgs. Lyngby, Denmark.

${ }^{3}$ Department of Physics and Cooperative Institute for Research in Environmental Sciences, University of Colorado, Boulder, Colorado, USA.

${ }^{4}$ Bristol Glaciology Centre, University of Bristol, Bristol, United Kingdom.

${ }^{5}$ Institute for Marine and Atmospheric Research, Utrecht University, Utrecht, The Netherlands.

Corresponding author: Dr. Shfaqat Abbas Khan, DTU Space Geodesy Elektrovej, Byg. 328 Kgs. Lyngby 2800 Denmark. (abbas@space.dtu.dk)

(C)2012. American Geophysical Union. All Rights Reserved. 2169-9313/13/2012JB009684
}

[3] Studies have been carried out using various methods to estimate the GrIS mass balance. Remote sensing techniques used to determine the ice sheet volume include airborne and satellite radar and laser methods [Howat et al., 2008; Hurkmans et al., 2012; Khan et al., 2010b; Pritchard et al., 2009; Thomas et al., 2006; Zwally et al., 2002] and measurements of ice flow of outlet glaciers using interferometric synthetic aperture radar from satellites [Joughin et al., 2010; Rignot et al., 2008, 2011]. Direct mass changes of the GrIS are obtained using gravitational change measurements from the Gravity Recovery and Climate Experiment (GRACE) satellite mission [Chen et al., 2007; Jacob et al., 2012; Luthcke et al., 2006; Rignot et al., 2011; Velicogna and Wahr, 2006; Wouters et al., 2008]. All of these methods have limitations. Satellite radar altimetry does not work well on sloping surfaces, and is affected by radar penetration into the snow. Interferometric synthetic aperture radar does not measure mass directly; it measures surface velocity, mainly for outlet glaciers, and the conversion to mass estimates requires a knowledge of outlet glacier thickness and of the depthdependent velocity profile. GRACE has limited spatial resolution and is affected by mass variations not just from ice changes, but also from hydrologic and ocean mass variability and from mass redistribution within the solid Earth. The accuracy of ice mass and ice volume estimates can be assessed by comparing the results from different techniques. Here, we focus on volume loss estimates from Ice, Cloud and land 


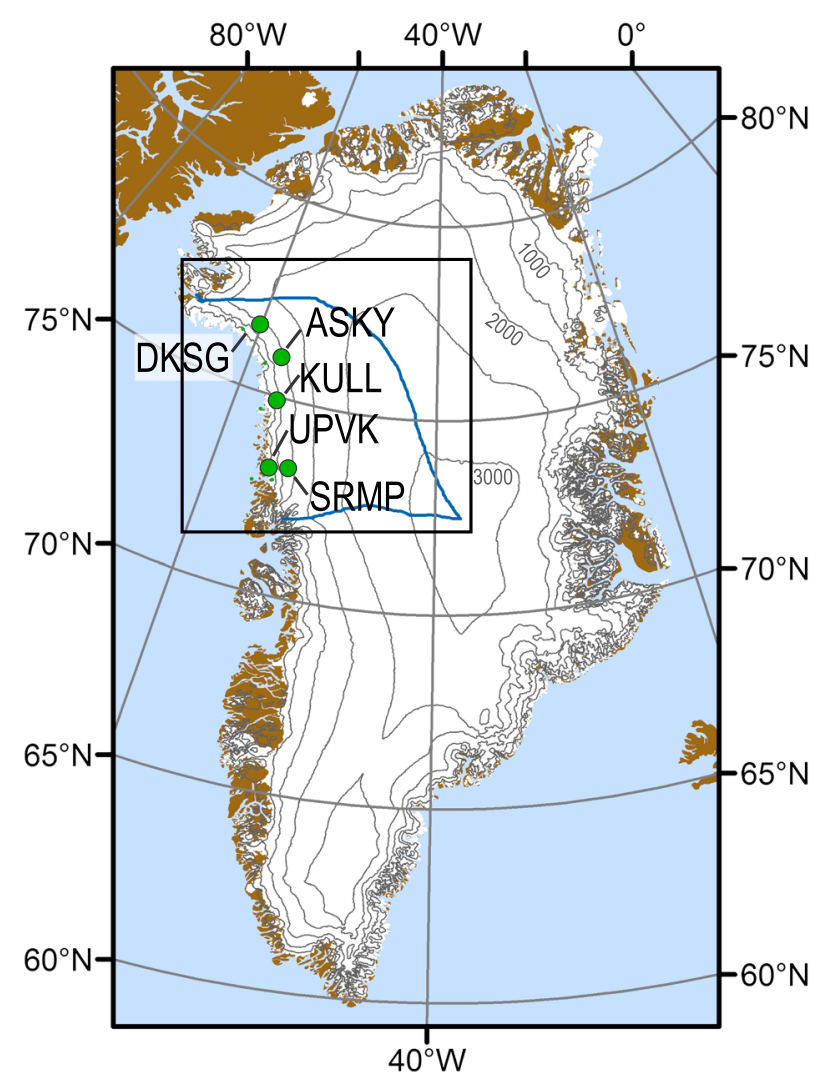

Figure 1. Map of Greenland and the Greenland ice sheet. The blue box shows the study area. Green circles denote locations of GNET GPS stations. The solid curves delineate elevation contours at $500 \mathrm{~m}$ intervals.

Elevation Satellite (ICESat), Airborne Topographic Mapper (ATM) and Land, Vegetation and Ice Sensor (LVIS) data.

[4] In this study, we focus on the northwest drainage basin of the GrIS, where Kjoer et al. [2012] recently reported substantial recurring dynamic thinning events. Dynamically induced ice loss and its associated ice surface lowering are often largest close to the glacier calving front, and the rates may vary from tens of meters per year to a few meters per year over relatively short distances $(5-10 \mathrm{~km})$ [Howat et al., 2007; Khan et al., 2007; Kjor et al., 2012; Liu et al., 2012; Nielsen et al., 2012; Stearns and Hamilton, 2007]. Hence, high spatial resolution data are required to estimate volume changes accurately. To assess this, three models have been derived to estimate the volume change rates during 20032010. The first model is based solely on ICESat data, while the second model is a composite of ICESat data supplemented by altimeter surveys from ATM during 2002-2010 [Krabill, 2011] and by LVIS data from 2010 [Blair and Hofton, 2010]. The third model is the same as the second, but only data from 2005-2010 are used to examine the dynamic behavior of the volume change rates. Our best estimates of ice surface elevation change rates during 20032010 for northwest Greenland (see Figure 1), delivered with a regular grid spacing of $200 \mathrm{~m} \times 200 \mathrm{~m}$, are available online for download at ftp://ftp.spacecenter.dk/abbas/ JGR2012.

[5] Furthermore, we use the three models to study the implications of volume change estimates on predictions of bedrock uplift caused by present-day ice mass variability. The recently established GPS Network in Greenland (GNET) [Bevis et al., 2012] uses GPS to measure displacements of bedrock near the margins of the GrIS. Bedrock displacements have contributions from post-glacial rebound (PGR), which is the Earth's viscoelastic response to ice mass variability over the last several thousand years, and to the elastic adjustment of the lithosphere caused by present-day ice mass changes [Wahr et al., 2001]. To assess PGR models using measured uplift from GPS [Dietrich et al., 2005; Fleming and Lambeck, 2004; Johansson et al., 2002; Khan et al., 2008; King et al., 2010; Larsen et al.; 2005; Spada et al., 2012; Wahr et al., 2001] and to isolate bedrock displacements caused by PGR, the uplift caused by the presentday ice mass loss must be predicted and removed from the GPS observations. Here, we study the relative impact of incorrectly-modeled ice loads on the prediction of elastic uplift at GNET GPS sites in northwestern Greenland (see Figure 1). Since the GPS stations in this area were established in the summer of 2007 and our volume loss estimates cover 2003-2010, we do not compare the predictions with the observed uplift rates; rather, the goal is to assess the uncertainties of predicted elastic displacements caused by present-day surface load changes. Hence, the relative differences between the predicted uplifts based on the three models are of greater importance.

[6] Furthermore, it is important to note that a precise prediction of elastic displacements depends on the accuracy of the load model (as discussed in this study) and the accuracy of the Earth model (elastic parameters). The latter is not discussed in this study. To predict elastic displacements, we simply use the Green's function for vertical displacements derived by Jean-Paul Boy [Petrov and Boy, 2004] on the basis of the Preliminary Reference Earth Model [Dziewonski and Anderson, 1981], and instead focus on the load and its uncertainty. The aim of this paper is to assess the value of combining ICESat data with ATM and LVIS data to determine volume change rates, and to discuss the implications for isolating PGR signals in Greenland GPS measurements.

\section{Data}

[7] We use ICESat GLA12 Release 31 data [Zwally et al., 2011] obtained from the National Snow and Ice Data Center to estimate ice elevation changes within the northwest Greenland drainage basin (marked by the blue line in Figure 2a). The GeoscienceLaser Altimeter System instrument on ICESat provides measurements of ice sheet elevations on the TOPEX/Poseidon ellipsoid, which were converted to the WGS84 ellipsoid. The satellite laser footprint diameter is 30 $70 \mathrm{~m}$ and the distance between footprint centers is approximately $170 \mathrm{~m}$ [Zwally et al., 2011]. The most important biases come from pointing errors and saturation errors. ICESat elevations that have been corrected for both pointing and saturation errors, and that have been filtered for surface roughness and atmospheric scattering, have a crossover standard deviation of $\sigma_{\text {ICESat }}=0.2 \mathrm{~m}$ [Howat et al., 2008; NSIDC, 2010; Pritchard et al., 2009]. We have used all available 2003-2009 ICESat data.

[8] Complementing the ICESat data, we also employ elevation measurements from ATM flight-lines in this region 

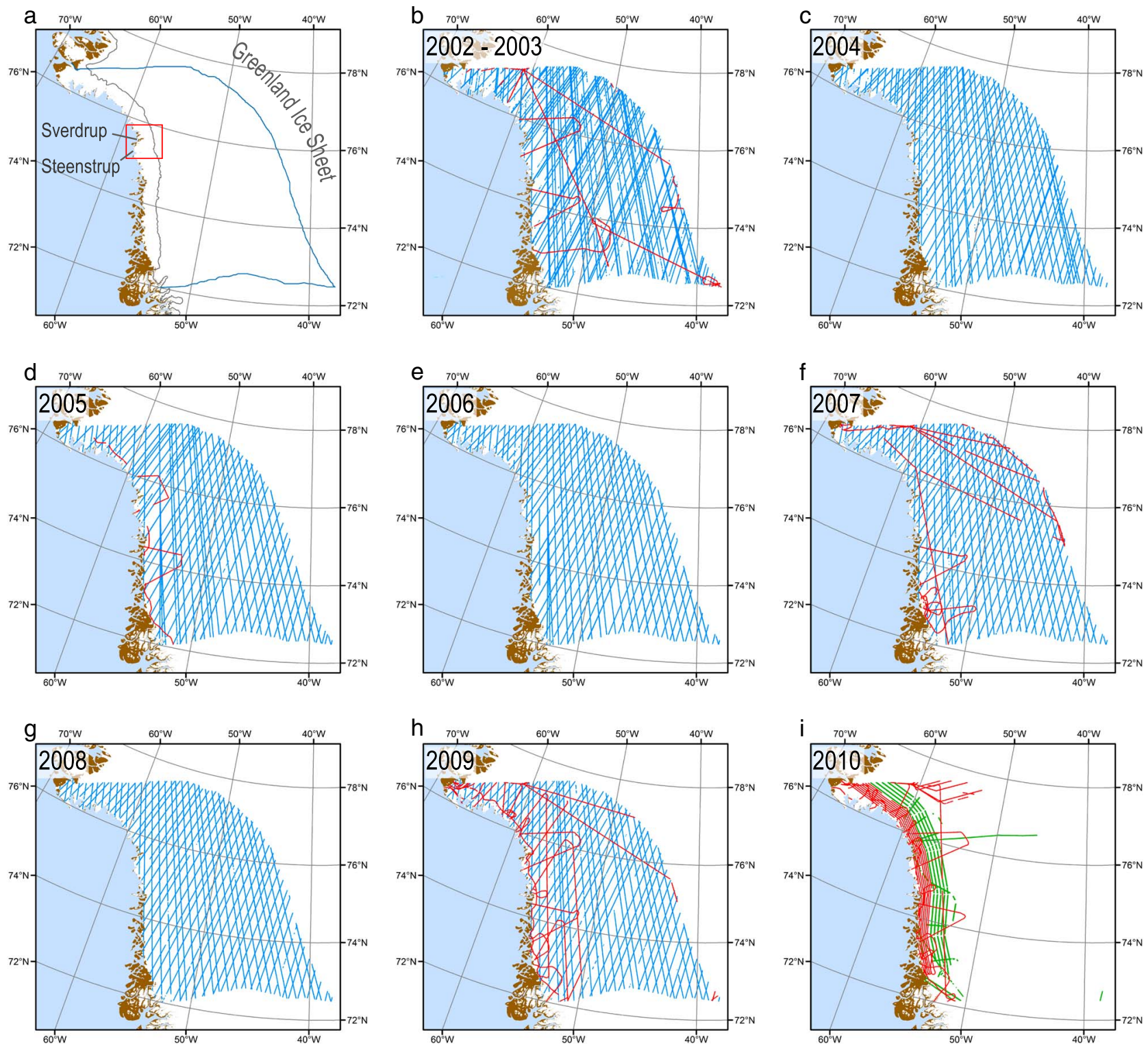

Figure 2. (a) (top left) The northwest Greenland drainage basin is marked by a blue line. The red box denotes the area shown in Figure 5. The solid black line along the margin represents ELA (1200 m elevation contour line). (b-i) Ground tracks for ICESat (blue line), ATM (red line), and LVIS (green line) for the years (b) 2002-2003, (c) 2004, (d) 2005, (e) 2006, (f) 2007, (g) 2008, (h) 2009, and (i) 2010.

for 2002, 2005, 2007, 2009, and 2010. The ATM measurements have an elevation standard deviation of $\sigma_{\mathrm{ATM}}=$ $0.1 \mathrm{~m}$ [Krabill et al., 2002]. Additionally, we use elevation measurements from LVIS flight-lines from 2010 [Blair and Hofton, 2010]. LVIS measurements have an elevation standard deviation of $\sigma_{\text {LVIS }}=0.1 \mathrm{~m}$ [Blair and Hofton, 2010]. Figures $2 \mathrm{~b}$ to $2 \mathrm{i}$ show ground tracks for ICESat (blue line), ATM (red line) and LVIS (green line) for (b) 20022003, (c) 2004, (d) 2005, (e) 2006, (f) 2007, (g) 2008, (h) 2009, and (i) 2010.

[9] To provide independent observations of the timing of ice loss in northwest Greenland we used data from the GRACE satellite mission. The gravity data are provided in monthly sets of spherical harmonic coefficients. These coefficients are transformed into surface mass on a $0.5 \times 0.5$ degree grid and smoothed with a Gaussian smoothing function of $250 \mathrm{~km}$ half-width [Wahr et al., 1998]

\section{Data Analysis}

\subsection{ICESat, ATM, and LVIS data}

[10] To derive ice surface change estimates, we first divide the entire northwest Greenland drainage basin into $500 \mathrm{~m} \times$ $500 \mathrm{~m}$ cells. We assume the ice surface of cell $(i, j)$ includes a seasonal term and a secular term. Thus, the observed height $H_{i j}$ of the $(i, j)$ 'th cell at time $t$ can be expressed as

$$
\begin{aligned}
H_{i j}(t)= & a_{i j} t+b_{i j}+\alpha_{i j} \cos (\omega t)+\beta_{i j} \sin (\omega t)+S E_{i j}\left(E-E_{i j}^{0}\right) \\
& +S N_{i j}\left(N-N_{i j}^{0}\right)
\end{aligned}
$$


where $a_{i j}$ represents the secular term and $b_{i j}$ an offset. The seasonal term is described by the $\alpha_{i j}$ and $\beta_{i j}$,

$$
A_{i j} \cos \left(\omega t+\phi_{i j}\right)=\alpha_{i j} \cos (\omega t)+\beta_{i j} \sin (\omega t)
$$

where $\omega$ is the frequency of the annual term, $A_{i j}$ and $\phi_{i j}$ are the amplitude and phase of the annual term, respectively. $\left(E-E_{i j}^{0}\right)$ and $\left(N-N_{i j}^{0}\right)$ are the Easting and Northing observations relative to the nominal cell center coordinates $E_{i j}^{0}$ and $N_{i j}^{0}$ of the $(i, j)^{\prime}$ th cell. Satellite and airborne laser altimetry provide accurate measurements of ice sheet surface elevation. However, measurements are not repeated at exactly the same location, which makes a surface slope correction necessary [Howat et al., 2008; Pritchard et al., 2009]. $S E_{i j}$ is the ice slope of the $(i, j)$ 'th cell in the eastern direction, while $N E_{i j}$ is the ice slope of the $(i, j)$ 'th cell in the northern direction:

$$
S E_{i j}=\left(\frac{d H}{d E}\right)_{i j}, S N_{i j}=\left(\frac{d H}{d N}\right)_{i j}
$$

[11] Our procedure for deriving ice surface elevation changes is similar to the method used by, for example, Ewert et al. [2012], Howat et al. [2008], and Smith et al. [2009]. For each $(i, j)$ 'th cell-point in the northwest Greenland drainage basin we search for all available ICESat (and for some models ATM and LVIS) data points located within the cell. Thus, we find all data points within the $500 \mathrm{~m} \times 500 \mathrm{~m}$ box and simultaneously fit (using least squares) annually and secularly varying terms, and slopes in the easterly and northerly directions. Next, we use the observed ice elevation change rates with their associated uncertainties to interpolate ice thinning values onto a $200 \mathrm{~m} \times 200 \mathrm{~m}$ grid. We use this $200 \mathrm{~m}$ grid because some of the GPS stations are located only a few kilometers from the ice margin, and this finer resolution is needed when modeling deformation from loads that near. Moreover, we use a land-ice mask of approximately $150 \mathrm{~m}$ resolution, so that we can estimate the uplift at adjacent GPS locations more accurately. The ice elevation change rates and their associated uncertainties are interpolated using the kriging method in the GRAVSOFT software package [Forsberg and Tscherning, 2008].

[12] Figure 3 shows the ice elevation change rates derived for the three different models (negative rates mean ice thinning). The uncertainties are smallest along ICESat, ATM, or LVIS ground tracks and largest between the tracks. For model 1 we use all available ICESat data during 2003-2009 in the northwest drainage basin, and simultaneously fit annually and secularly varying terms and slopes in the easterly and northerly directions. The ice elevation change rates in meters per year during 2003-2009 are displayed in Figure $3 \mathrm{a}$, and their associated uncertainties are shown in Figure $3 \mathrm{~d}$.

[13] In model 2 we supplement 2003-2009 ICESat data with ATM data from 2002, 2005, 2007, 2009, 2010, and with LVIS data from 2010. We combine the ICESat, ATM, and LVIS data and simultaneously fit annually and secularly varying terms and slopes in the easterly and northerly directions. The ice elevation change rates obtained during 2003-2010 using model 2 and their associated uncertainties are displayed in Figures $3 \mathrm{~b}$ and $3 \mathrm{e}$, respectively.
[14] To study changes in volume loss reported in 2005 [e.g., Joughin et al., 2010; Khan et al., 2010a; Kjoer et al., 2012; Pritchard et al., 2009; Sasgen et al., 2012], we introduce a third model that is similar to model 2 , but only uses data from 2005-2010. Thus, we use ICESat data from 20052009, ATM data from 2005, 2007, 2009, 2010, and LVIS data from 2010. The only difference between models 2 and 3 is the data time span. Ice elevation change rates obtained during 2005-2010 using model 3 and their associated uncertainties are displayed in Figures $3 \mathrm{c}$ and $3 \mathrm{f}$.

\subsection{Elevation Change Due to Firn Compaction and SMB Variability}

[15] Conversion of the volume loss rates obtained using models 1-3 into mass loss rates requires assumptions about the density of the snow-ice column. Firn compaction must be included to convert volume to mass. Elevation changes due to firn compaction are computed using a simple firn model that includes melt and refreezing [Reeh, 2008]. It is forced by annual temperatures, accumulation, melt, and refreezing from the regional climate model RACMO2 [Ettema et al., 2009; Van Angelen et al., 2012]. RACMO2 was run for Greenland at $11 \mathrm{~km}$ resolution for the period 1958-2010, using lateral boundary conditions from the European Centre for Medium-Range Weather Forecasts reanalyses (ERA-40 and ERA-Interim). Based on a comparison with observations, Ettema et al. [2009] concluded that RACMO2 performs well $(N=265, r=0.95)$, yielding a $14 \%$ uncertainty in ice sheet integrated surface mass balance (SMB). For every year, SMB in the simple firn model is calculated from RACMO2 fields as the sum of accumulation and refreezing minus melt, all with units $\left[\mathrm{m}\right.$ ice $\left.\mathrm{yr}^{-1}\right]$. The firn model assumes that all processes take place in the surface layer (i.e., that there is no meltwater percolation). The surface layer contains a fraction of snow, and, where melt and refreezing occur, a fraction of refrozen ice. The layer of refrozen ice that remains at the end of the melt season (hereafter referred to as SIR or Superimposed Ice Remaining) is equal to the refreezing from RACMO2, albeit constrained to be between zero and SMB. The thickness and density of each annual layer is then the total of the two fractions, where the density of the firn layer at deposition is calculated by Reeh et al., 2005

$$
\rho_{s 0}=625+18.7 T_{f}+0.293 T_{f}^{2}
$$

where $T_{f}$ is the firn temperature at $10 \mathrm{~m}$ depth in ${ }^{\circ} \mathrm{C}$, which depends on the mean annual temperature TMA and on SIR [Reeh, 1991]

$$
T_{f}=T M A+26.6 S I R
$$

As the surface layer is covered by subsequent layers, firn compaction occurs, and hence the density of the firn fraction will increase and the thickness of the layer will decrease. To model the firn compaction process, the parameterization by Zwally and Jun [2002] was used

$$
\rho_{s}\left(t_{0}, t\right)=\rho_{i}-\left(\rho_{i}-\rho_{s 0}\left(t_{0}\right)\right) e^{-c t},
$$




\section{KJELDSEN ET AL.: IMPROVING ICE VOLUME LOSS}
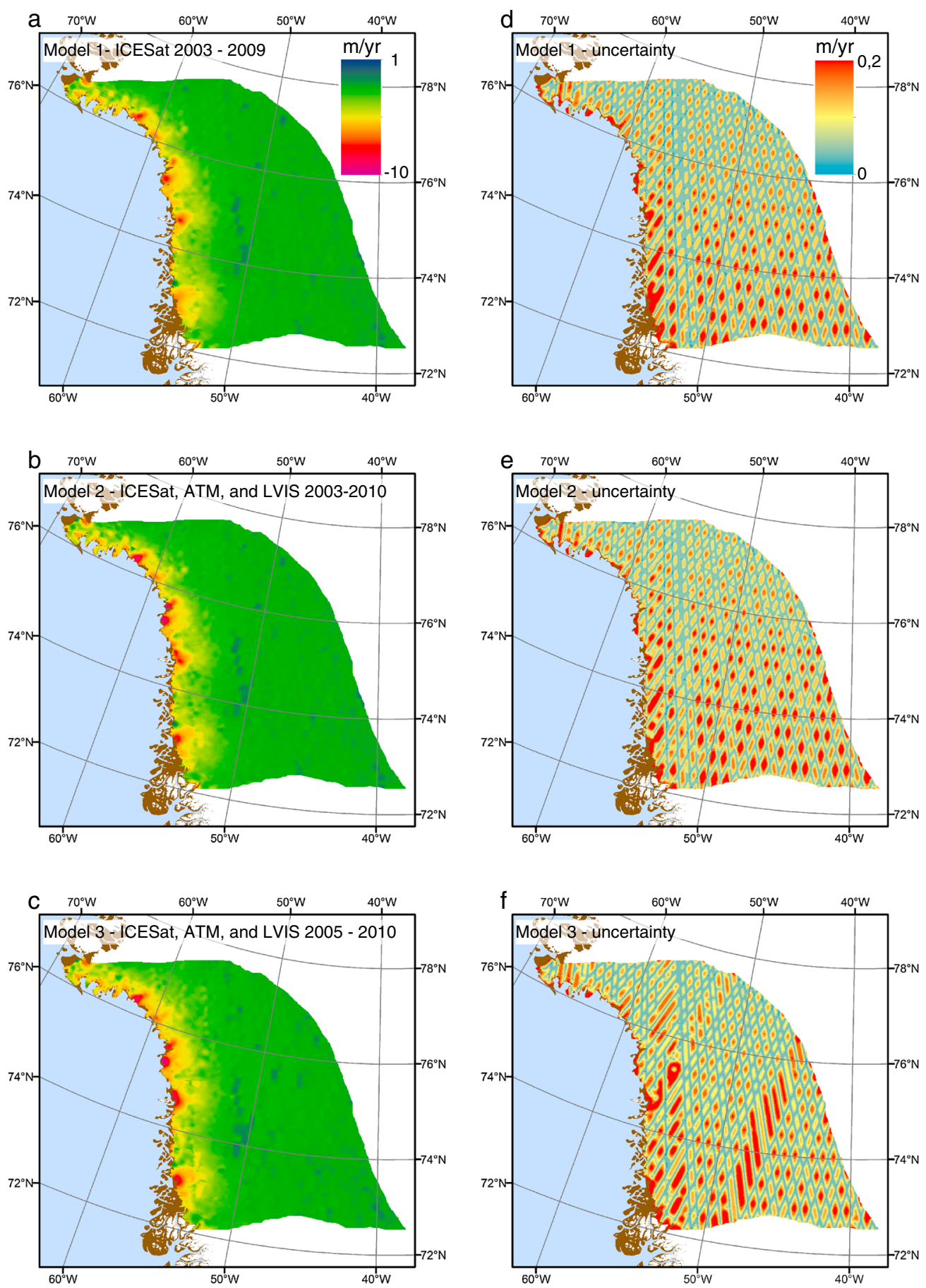

Figure 3. Ice surface elevation change rates in $\mathrm{myr}^{-1}$ and their corresponding uncertainties. (a) Model 1, Elevation change rates using 2003-2009 ICESat data, (b) model 2, elevation change rates using 20032010 ICESat, ATM, and LVIS data, (c) model 3, elevation change rates using 2005-2010 ICESat, ATM, and LVIS data. (d-f) Estimated uncertainties associated with Figures 3a-3c. Resolution of all grids is $200 \mathrm{~m}$.

where $c$ is given by

$c=\overline{S M B}\left(\frac{\rho_{i}}{\rho_{w}}\right)\left(139.21-0.542\left(\bar{T}_{f} 273.15\right)\right) 8.36\left(273.15-\left(\bar{T}_{f}\right)\right)^{-2.061}$,

where $\rho_{\mathrm{w}}$ is the density of water $\left(1000 \mathrm{~kg} \mathrm{~m}^{-3}\right), \rho_{\mathrm{i}}$ is the density of solid ice $\left(917 \mathrm{~kg} \mathrm{~m}^{-3}\right)$, and $\overline{S M B}$ and $\bar{T}_{f}$ are the long- term average surface mass balance and firn temperature, respectively. The elevation change induced by SMB variability is taken as the difference between the thickness of the surface layer and the thickness of the reference surface layer (the 1961 to 1990 average). The elevation change due to firn compaction at a given time is calculated as the difference between the sum of the thickness of 99 annual layers (not the surface layer) that have each compacted for 

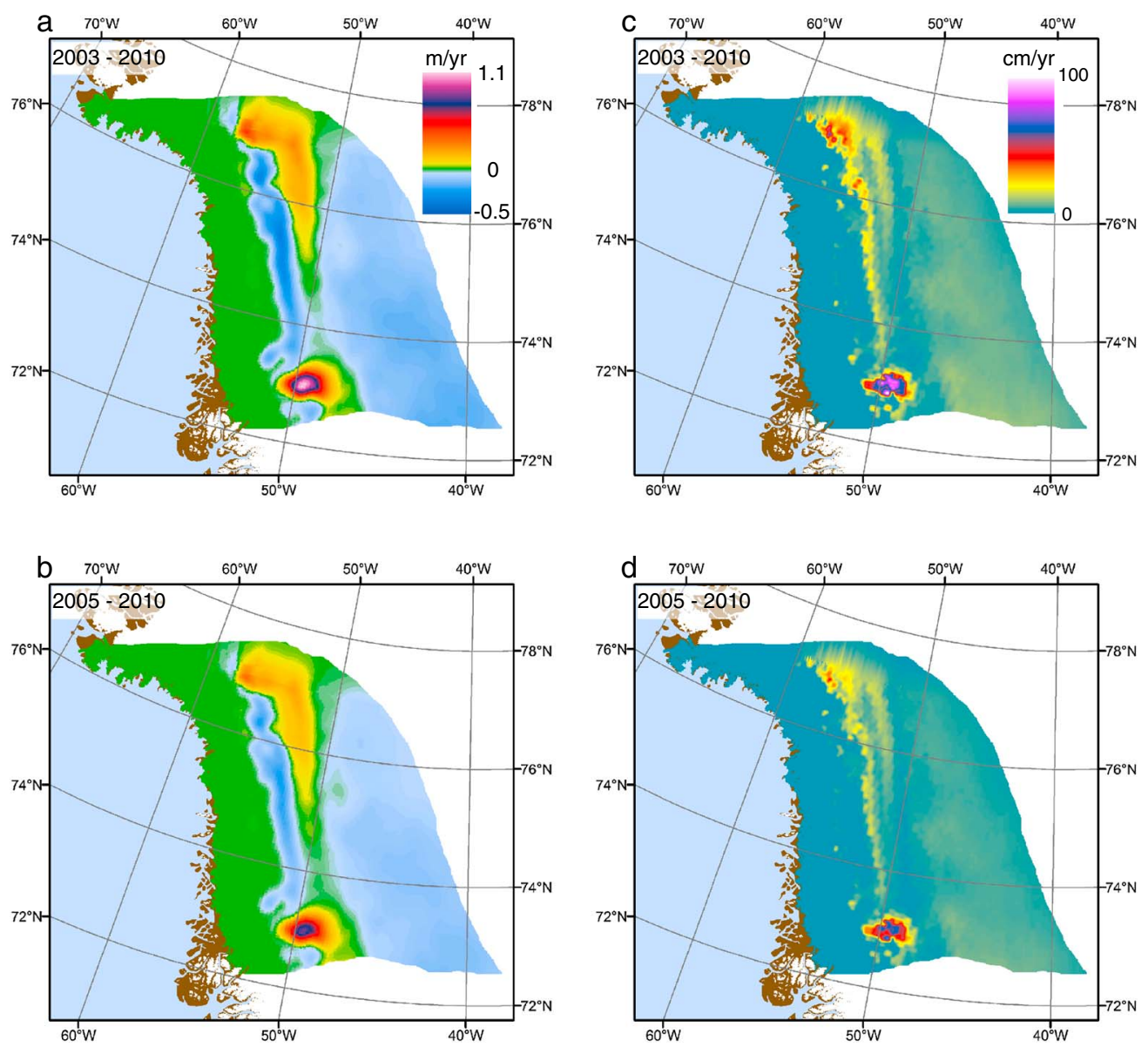

Figure 4. Elevation changes due to firn compaction during (a) 2003-2010 and (b) 2005-2010, respectively, and the associated uncertainties for (c) 2003-2010 and (d) 2005-2010.

the appropriate amount of time, and the 1961-1990 average. To obtain data for the periods in this study, we assumed that annual layers are based on years from 1 April to 31 March. We then summed elevation changes due to SMB and firn compaction over the periods 2003-2010 and 20052010. Because the RACMO run started in 1960 and our analysis starts in 2003, the upper 43 layers of the profile were modeled, and the profile was completed using the lower 57 layers from the reference firn profile (i.e., the 1961-1990 average). To estimate the errors in elevation changes due to SMB and firn compaction, we assumed the accuracy of the SMB and temperature produced by RACMO2 [Ettema et al., 2009, 2010], and propagated the uncertainty through the model. The elevation changes due to firn compaction are shown in Figures $4 \mathrm{a}$ and $4 \mathrm{~b}$ for 2003-2010 and 20052010, respectively, and the associated uncertainties for
2003-2010 and 2005-2010 are displayed in Figures 4c and $4 \mathrm{~d}$, respectively.

\section{Results}

[16] The estimated volume change rates using models 1-3 are summarized in Table 1 . We obtain a 2003-2009 ice volume change rate of $-50.8 \pm 9.1 \mathrm{~km}^{3} \mathrm{yr}^{-1}$ (a negative rate means ice volume loss) when using ICESat data only (model 1). Supplementing the ICESat data with ATM and LVIS data (model 2) increases the ice volume change rate by $10 \%$ to $-55.8 \pm 8.4 \mathrm{~km}^{3} \mathrm{yr}^{-1}$. Taking the estimated uncertainties into account, there is no significant difference between model 1 and 2 when the catchment-wide volume loss is considered. However, the difference is significant for volume change rate at elevations below $1200 \mathrm{~m}$, the approximate equilibrium line

Table 1. Estimates of Ice Volume and Mass Volume Change

\begin{tabular}{|c|c|c|c|c|c|c|}
\hline \multirow[b]{2}{*}{ Model } & \multirow[b]{2}{*}{ Data Source } & \multirow[b]{2}{*}{$\begin{array}{l}\text { Time Span } \\
\text { (year) }\end{array}$} & \multicolumn{2}{|c|}{ Ice Volume Change Rate } & \multirow[b]{2}{*}{$\begin{array}{l}\text { \% Ice Loss Below } \\
1200 \mathrm{~m} \text { Elevation \% }\end{array}$} & \multirow[b]{2}{*}{$\begin{array}{l}\text { Ice Mass Loss } \\
\left(\mathrm{Gt} \mathrm{yr}^{-1}\right)\end{array}$} \\
\hline & & & $\begin{array}{l}\text { Entire Basin } \\
\left(\mathrm{km}^{3} \mathrm{yr}^{-1}\right)\end{array}$ & $\begin{array}{l}\text { Below ELA } \\
\left(\mathrm{km}^{3} \mathrm{yr}^{-1}\right)\end{array}$ & & \\
\hline 1 & ICESat & 2003-2009 & $-50.8 \pm 9.1$ & $-36.3 \pm 1.2$ & 71 & $-35.4 \pm 8.3$ \\
\hline 2 & ICESat, ATM, LVIS & $2003-2010$ & $-55.8 \pm 8.4$ & $-41.3 \pm 1.0$ & 74 & $-40.0 \pm 7.7$ \\
\hline 3 & ICESat, ATM, LVIS & $2005-2010$ & $-72.8 \pm 9.5$ & $-47.0 \pm 1.2$ & 65 & $-59.4 \pm 8.7$ \\
\hline
\end{tabular}




\section{KJELDSEN ET AL.: IMPROVING ICE VOLUME LOSS}
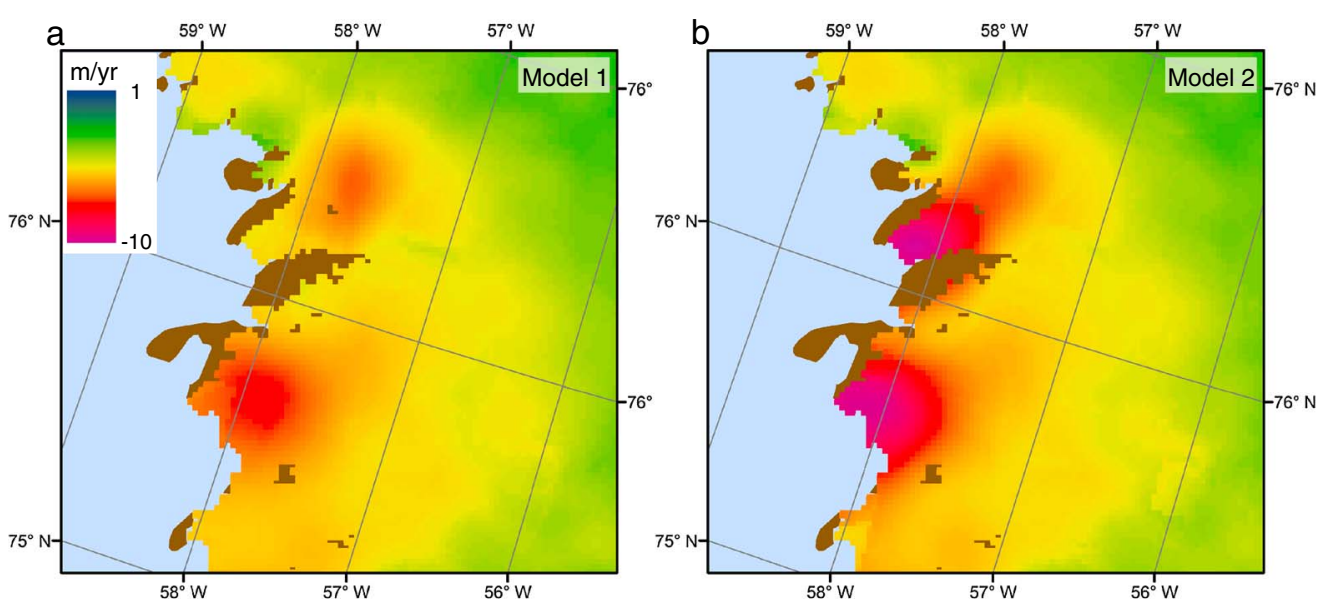

Figure 5. Same as Figures $3 \mathrm{a}-3 \mathrm{~b}$ but only for the area marked by the red box on Figure $2 \mathrm{a}$. The maps show ice surface elevation change rates, in $\mathrm{m} \mathrm{yr}^{-1}$, focused in on Sverdrup and Steenstrup glaciers. (a) Elevation change rates using 2003-2009 ICESat data, (b) elevation change rates using 2003-2010 ICESat, ATM, and LVIS data.

altitude (ELA) [Zwally et al., 2005]. We obtain ice volume change rates (below $1200 \mathrm{~m}$ ) of $-36.3 \pm 1.2 \mathrm{~km}^{3} \mathrm{yr}^{-1}$ for model 1. Supplementing the ICESat data with ATM and LVIS data increases the ice volume change rate (below $1200 \mathrm{~m}$ ) by $14 \%$ to $-41.3 \pm 1.0 \mathrm{~km}^{3} \mathrm{yr}^{-1}$. There are three plausible explanations for the increased ice loss rate below $1200 \mathrm{~m}$. These are (1) that northwest Greenland experienced a large acceleration in ice loss between 2009 and 2010, or (2) that there is disagreement between the combined ATM/ LVIS data and the ICESat data at common points, or (3) that the volume loss rate in model 1 is underestimated because of incomplete ICESat sampling of the region. As discussed in the next section, explanation (1) seems to contradict GRACE observations.

[17] Figure 5 shows a close-up map of model 1 and model 2 over Sverdrup and Steenstrup glaciers. Figure 5a shows elevation change rates using 2003-2009 ICESat data, while Figure 5b shows 2003-2010 elevation change rates using ICESat, ATM, and LVIS data. The differences near the glacier margins are striking. Furthermore, model 1 predicts a smaller maximum thinning rate on Sverdruip glacier, than model 2. The differences are due to the fact that model 2 contains a greater number of observations, especially near the ice margin where the changes are largest; hence, model 2 improves the estimated thinning rates.

[18] Improvement is not uniform throughout the region but is governed by the density of points. By subtracting model 1 from model 2, the impact becomes more directly visible (Figure 6a). Figure 6b shows the differences in elevation change rates on Sverdrup and Steenstrup glaciers, where model 1 gives smaller thinning rates by up to $8.6 \mathrm{~m} \mathrm{yr}^{-1}$. In general, differences are largest near the frontal portion of outlet glaciers. It is unlikely that measurements from ATM and LVIS flight-lines in this region are biased by several meters along glacier flow lines (and not between glaciers). This implies that explanation (2) above is unlikely.

[19] The catchment-wide ice volume change rate derived from model 3, which uses 2005-2010 ICESat, ATM, and LVIS data, yields $-72.8 \pm 9.5 \mathrm{~km}^{3} \mathrm{yr}^{-1}$. This suggests an increased ice volume loss for 2005-2010 relative to 20032005. The increased ice volume loss rate in northwest Greenland is consistent with results from other techniques,
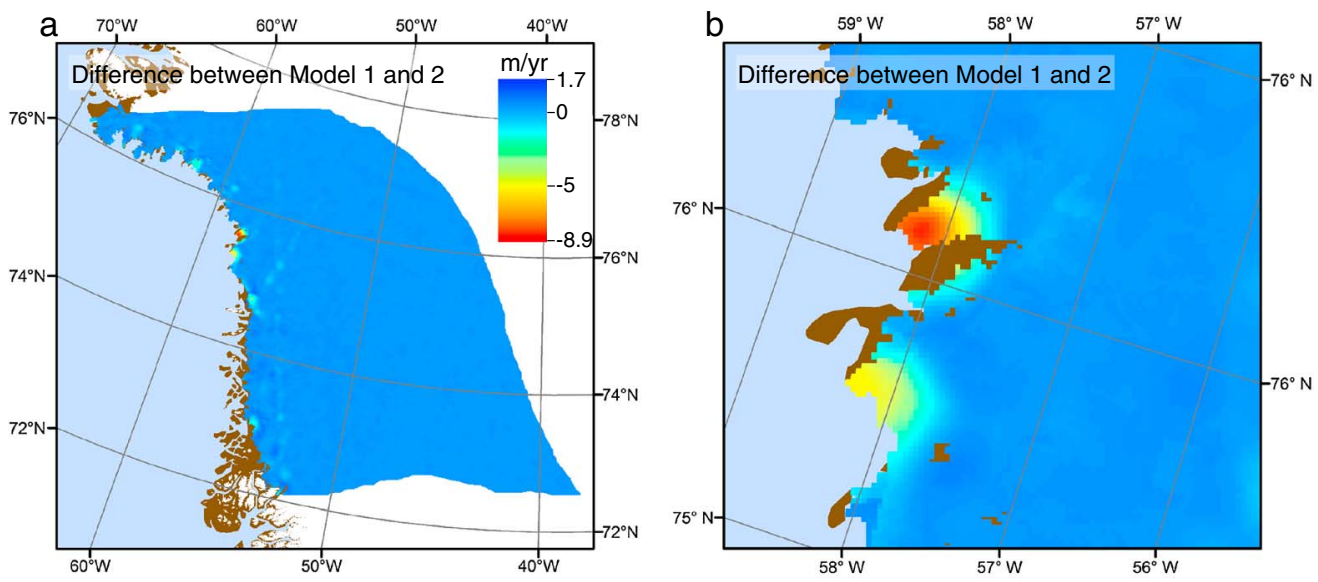

Figure 6. (a) Differences in elevation change rates in $\mathrm{m} \mathrm{yr}^{-1}$ between models 1 and 2 (model 2 minus model 1). (b) Same as Figure 6a but focused in on Sverdrup and Steenstrup glaciers. 


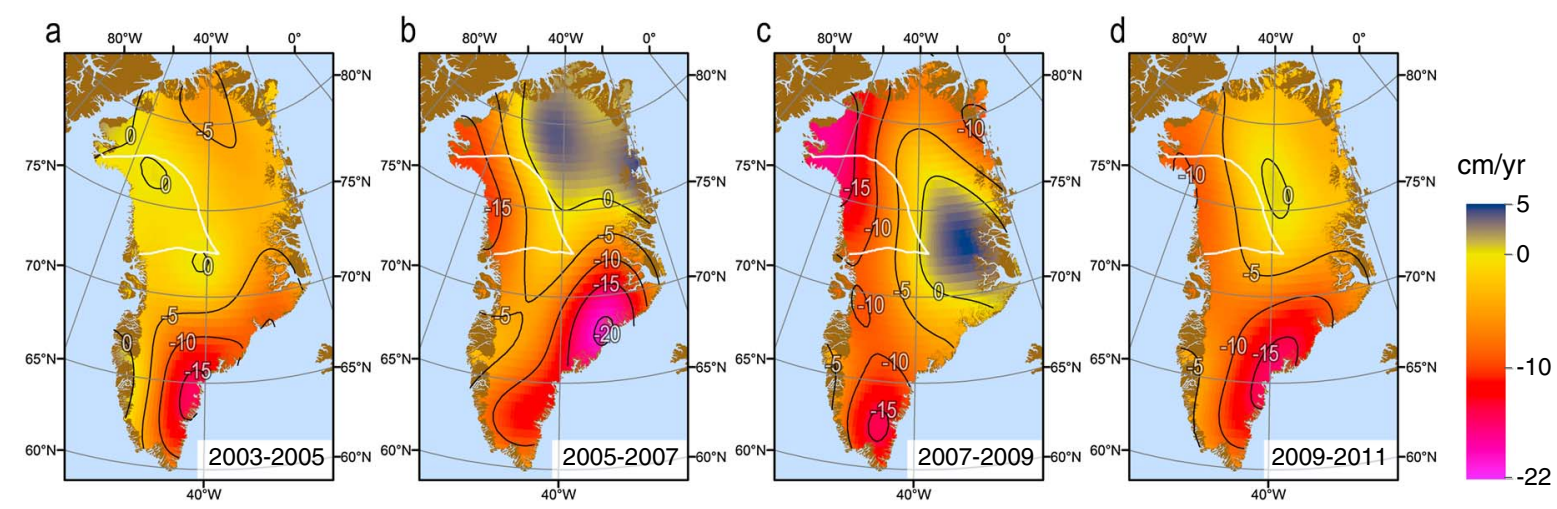

Figure 7. Catchment-wide mass change rates across the Greenland ice sheet, extracted from GRACE for 2003-2011, in units of $\mathrm{cm} \mathrm{yr}^{-1}$ of water thickness, inferred from consecutive 2 year periods (from April to April). Solid black lines denote water thickness contours at $5 \mathrm{~cm} \mathrm{yr}^{-1}$ intervals. The solid white line marks the northwest Greenland drainage basin. The results have been smoothed with a Gaussian smoothing function with a $250 \mathrm{~km}$ half-width.

such as GRACE and GPS, which suggest an increased ice loss along the northwest coast starting in 2005/2006 and running through 2009 [Joughin et al., 2010; Khan et al., 2010a; Kjoer et al., 2012; Pritchard et al., 2009; Sasgen et al., 2012; Velicogna, 2009].

[20] Table 1 summarizes the derived ice volume and mass loss change rates from the three models. Column 5 shows that most of the increase in the ice volume rates between model 1 and 2 comes from elevations below $1200 \mathrm{~m}$. This underlines the impact of the additional data used in model 2 that are not included in model 1, and shows the importance of capturing elevation changes along the ice margin. Of the entire observed thinning and volume loss, $65-74 \%$ occurs at elevations below $1200 \mathrm{~m}$.

\subsection{Slow-Down of Ice Mass Loss During 2009-2011}

[21] To see whether the inclusion of 2010 ATM and LVIS data might be biasing our model comparisons, we have incorporated GRACE measurements into our study. Figure 7 shows mass changes of the GrIS extracted from GRACE measurements for 2003-2011 in units of centimeters per year of water thickness, inferred from consecutive 2 year periods (from April to April). Figures 7c and 7d suggest a slow-down of ice mass loss in northwest Greenland during 2009-2011 relative to 2007-2009. This contradicts plausible explanation (1) above, that the $5 \mathrm{~km}^{3} \mathrm{yr}^{-1}$ difference between models 1 and 2 is caused by increased ice loss in 2009-2010. Hence, the volume change rate difference is most likely caused by underestimated ice loss near the margin in model 1. Furthermore, Figure 7a shows no significant ice loss in northwest
Greenland during 2003-2005, which is consistent with models 2 and 3 that suggest increased ice loss starting about 2005.

\subsection{Implications for Solid Earth Deformation}

[22] The GPS Network in Greenland (GNET) uses GPS to measure the displacement of bedrock near the margins of the GrIS. Figure 1 (green circles) shows the locations of GNET sites in northwest Greenland. Upernavik (UPVK) and Kullorsuaq (KULL) are located approximately $60 \mathrm{~km}$ and $25 \mathrm{~km}$ from the ice margin, respectively. Sermip Nuunataa (SRMP), Doecker Smith Gletscher (DKSG), and Astrup Kystland (ASKY) are all located a few kilometers from the ice margin. These stations were not established until the summer of 2007, so we cannot compare the observed and modeled uplift rates caused by surface mass load variability. Instead we assess the uncertainties of the predicted elastic displacements at the five GPS locations associated with present-day surface load changes, and their effects on the use of the GPS data to validate the PGR models. Hence, we focus on assessing the relative differences in predicted uplift between the different ice volume change models presented above. We use the ice thinning rates displayed in Figure 3, combined with the firn compaction from Figure 4, to predict the Earth's elastic response to present-day ice mass variability from the entire drainage basin. Table 2 shows the predicted elastic uplift rates in millimeters per year obtained by convolving mass loss estimates with the Green's function for vertical displacements derived by Jean-Paul Boy [Petrov and Boy, 2004] for the Preliminary Reference Earth Model [Dziewonski and Anderson, 1981].

Table 2. Predicted Elastic Uplift Rates Obtained Using Models 1-3 from Table 1, and Predicted Uplift Rates From the PGR Models ICE-5 G and HUY2

\begin{tabular}{lccccc}
\hline Site Name & $\begin{array}{c}\text { Model 1 } \\
\left(\mathrm{mm} \mathrm{yr}^{-1}\right)\end{array}$ & $\begin{array}{c}\text { Model 2 } \\
\left(\mathrm{mm} \mathrm{yr}^{-1}\right)\end{array}$ & $\begin{array}{c}\text { Model 3 } \\
\left(\mathrm{mm} \mathrm{yr}^{-1}\right)\end{array}$ & $\begin{array}{c}\text { Diff. Between Max-Min } \\
\left(\mathrm{mm} \mathrm{yr}^{-1}\right)\end{array}$ & $\begin{array}{c}\text { ICE-5 G } \\
\left(\mathrm{mm} \mathrm{yr}^{-1}\right)\end{array}$ \\
\hline UPVK & $2.8 \pm 0.3$ & $3.0 \pm 0.3$ & $3.6 \pm 0.3$ & 0.8 & -1.4 \\
SRMP & $9.5 \pm 0.6$ & $10.5 \pm 0.6$ & $12.7 \pm 0.6$ & 3.2 & -1.6 \\
KULL & $5.3 \pm 0.5$ & $5.9 \pm 0.4$ & $7.3 \pm 0.5$ & -1.2 & -1.7 \\
DKSG & $14.0 \pm 0.6$ & $16.2 \pm 0.5$ & $17.7 \pm 0.6$ & -1.6 & -1.6 \\
ASKY & $8.3 \pm 0.6$ & $9.9 \pm 0.6$ & $12.9 \pm 0.6$ & -0.3 & -1.0 \\
\hline
\end{tabular}


[23] UPVK is the furthest distance from the ice margin and shows the smallest variation in uplift rate from the three ice load models. The difference between the lowest and highest uplift rate is $0.8 \mathrm{~mm} \mathrm{yr}^{-1}$. The differences between the lowest and highest uplift rates at SRMP, DKSG, and ASKY are all larger than $3 \mathrm{~mm} \mathrm{yr}^{-1}$.

[24] The predicted viscoelastic response to past ice mass variability from the global deglaciation model ICE-5G [Peltier, 2004] and the Greenland model HUY2 [Simpson et al., 2009; Simpson et al., 2011] are listed in the last two columns of Table 2. We use uplift rates calculated and made available by W R Peltier (http://www.atmosp.physics.utoronto.ca/ peltier/data.php) and Matthew Simpson (see auxiliary material of Simpson et al. [2011]). The HUY2 model includes non-Greenland ice and ocean loading changes from ICE-5 G. HUY2 uses an Earth model characterized by a $120 \mathrm{~km}$ lithosphere, an upper mantle viscosity of $5 \times 10^{20} \mathrm{Pas}$, and a lower mantle viscosity of $10^{21} \mathrm{Pas}$. The ICE-5 G model uses an Earth model characterized by a $90 \mathrm{~km}$ lithosphere and the VM2 viscosity profile. A detailed description of the VM2 viscosity profile can be obtained from: http://www.atmosp.physics.utoronto.ca/ peltier/datasets/ visc models/VM2_L90.txt. The differences between the two models are less than $0.5 \mathrm{~mm} \mathrm{yr}^{-1}$ in northwest Greenland, but are much larger in other coastal areas of Greenland, and are caused by differences in the Earth model and ice loading history. Correcting the observed GPS rates for elastic displacement using model 1 , and using the residuals to assess PGR models, would result in an incorrect interpretation of the PGR signal. The small difference in the predicted viscoelastic response from the PGR models implies that in order to assess the latter models, the relatively large differences in the predicted uplift from models 1, 2, and 3 are severe and must be taken into account. Hence, for validation of PGR models using GPS uplift rates near regions undergoing present-day ice changes, attention must be paid to the correct modeling of the ice loss. A small error in the uplift rate estimate for these sites could significantly influence the conclusions concerning mantle viscosity and ice-sheet history.

\section{Discussion and Conclusions}

[25] We have constructed three models of volume change rates for the northwest Greenland drainage basin. Model 1 uses ICESat data alone. In model 2 we supplement the ICESat data with ATM and LVIS data, and obtain an increase in the ice loss rate of $5 \mathrm{~km}^{3} \mathrm{yr}^{-1}$ over model 1. This is equal to $10 \%$ of the total drainage basin rate. Table 1 suggests that this increase is due to the ability of model 2 to detect changes at elevations below $1200 \mathrm{~m}$. At lower elevations, the ice loss increases from $36.3 \pm 1.2 \mathrm{~km}^{3} \mathrm{yr}^{-1}$ to $41.3 \pm$ $1.0 \mathrm{~km}^{3} \mathrm{yr}^{-1}$, an increase of $5 \mathrm{~km}^{3} \mathrm{yr}^{-1}$, which is equal to the difference at the drainage basin scale. The increase of about $14 \%$ is due to the fact that adding the ATM and LVIS data improves the resolution of thinning rates near the frontal portion of outlet glaciers (see Figures $3 a$ and $3 b$ ). The importance of higher data density near the margin of the ice sheet is also noted by Thomas et al. [2006], who stated that their ATM/ ICESat mass-budget estimate of the entire ice sheet based on ATM data from 1998/1989 and ICESat data from 2004 was an underestimate due to inadequate near-coastal coverage.
[26] Furthermore, using GRACE data for the northwest drainage basin, we find an annual mass loss rate of $39.1 \pm$ 6.8 $\mathrm{Gt} \mathrm{yr}^{-1}$ during 2003-2009. Ewert et al. [2012] estimated a rate of $41.1 \pm 8.1 \mathrm{Gt} \mathrm{yr}^{-1}$ for approximately the same area. However, the $\sim 200 \mathrm{~km}$ resolution of GRACE is not sufficient to isolate the source of mass loss in northwest Greenland. Both GRACE estimates could conceivably be biased by leakage from ice loss occurring just outside the northwest drainage basin.

[27] In model 3 we use all available data from 2005-2010 only, and obtain a volume loss rate of $59.4 \pm 8.7 \mathrm{Gt} \mathrm{yr}^{-1}$ for the entire northwest basin. The rate is much larger than the $40.0 \pm 7.7 \mathrm{Gt} \mathrm{yr}^{-1}$ ice loss rate observed during 2003-2010. This suggests a significant acceleration in mass loss, which is consistent with other studies [e.g., Joughin et al., 2010; Khan et al., 2010a; Kjor et al., 2012; Pritchard et al., 2009; Sasgen et al., 2012]. Furthermore, the percentage of the ice volume loss that occurred below a $1200 \mathrm{~m}$ elevation decreased from $74 \%$ during 2003-2010 to $65 \%$ during 2005-2010, suggesting that mass loss had spread to higher elevations (above $1200 \mathrm{~m}$ ) during 2005-2010.

[28] Our study shows that the relative difference between calculations of the predicted elastic uplift based on the three models is highly variable. This implies that assessing PGR models using observations of bedrock uplift from GPS is heavily affected by the ice mass loss model used to predict the elastic displacement. Many GNET GPS stations along the GrIS are located only a few kilometers from the ice margin. Our results suggest that sites located close to the ice margin can be strongly affected by the Earth's elastic response to present-day ice mass variability, and that high resolution data might be required to model and remove the elastic response accurately in order to assess the PGR signal. The use of ICESat data alone to predict elastic uplift rates could bias the predicted rates by several millimeters per year.

[29] The spacing between adjacent ICESat tracks increases with decreasing latitude. Hence, using only ICESat data in south Greenland may cause a significant underestimation of the total volume change, possibly by more than the $11 \%$ shown in this study for northwest Greenland. As shown by this study the underestimate is simply due to the lack of measurements near the frontal portion of outlet glaciers currently undergoing huge surface lowering, which may vary from tens of meters per year to a few meters per year over relatively short distances. This means that the use of ICESat data in southwest Greenland may be sufficient, since the frontal changes on glaciers in that region are small (with the exception of Jakobshavn Isbræ). However, glaciers in southeast Greenland recently experienced massive dynamically-induced surface lowering. Consequently, relying solely on ICESat data could lead to a significant underestimate of the total ice loss. Supplementing ICESat data with ATM and LVIS data in southeast Greenland could improve the ice loss estimation.

[30] Acknowledgments. We thank Tom Parsons, the Associate Editor, and two anonymous reviewers for ideas and suggestions on how to improve the manuscript. We thank Matthew Simpson for providing uplift rates based on the HUY2 ice load history. Shfaqat Abbas Khan was supported by Danish Commission for Scientific Research in Greenland KVUG (grant 11-104050) and Inge Lehmanns Legat. 


\section{KJELDSEN ET AL.: IMPROVING ICE VOLUME LOSS}

\section{References}

Blair, B., and M. Hofton (2010), IceBridge LVIS L2 Geolocated Ground Elevation and Return Energy Quartiles, [2010]. Boulder, Colorado USA: NASA Distributed Active Archive Center at the National Snow and Ice Data Center. Digital media. http://nsidc.org/data/ilvis2.html.

Bevis, M., et al. (2012), Bedrock displacements in Greenland manifest ice mass variations, climate cycles and climate change, Proc. Nat. Acad. Sci., 109(30), 11944-11948, doi:10.1073/pnas.1204664109.

Chen, J. L., C. R. Wilson, B. D. Tapley, D. D. Blankenship, and E. R. Ivins (2007), Patagonia icefield melting observed by gravity recovery and climate experiment (GRACE), Geophys. Res. Lett., 34, L22501, doi:10.1029/2007GL031871.

Dietrich, R., A. Rulke, and M. Scheinert (2005), Present-day vertical crustal deformations in West Greenland from repeated GPS observations, Geophys. J. Int., 163(3), 865-874, doi:10.1111/j.1365-246X.2005.02766.x.

Dziewonski, A., and D. Anderson (1981), Preliminary reference Earth model, Phys. Earth Planet. In., 25(4), 297-356.

Ettema, J., M. van den Broeke, E. van Meijgaard, W. J. van de Berg, J. L. Bamber, J. E. Box, and R. C. Bales (2009), Higher surface mass balance of the Greenland ice sheet revealed by high-resolution climate modeling, Geophys. Res. Lett., 36, L12501, doi:10.1029/2009GL038110.

Ettema, J., M. R. van den Broeke, E. van Meijgaard, W. J. van de Berg, J. E. Box, and K. Steffen (2010), Climate of the Greenland ice sheet using a high-resolution climate model Part 1: Evaluation, Cryosphere, 4, 561-602, doi:10.5194/tcd-4-561-2010.

Ewert, H., A. Groh, and R. Dietrich (2012), Volume and mass changes of the Greenland ice sheet inferred from ICESat and GRACE, J. Geodyn., 59-60, 111-123, doi:10.1016/j.jog.2011.06.003.

Fleming, K., and K. Lambeck (2004), Constraints on the Greenland Ice Sheet since the Last Glacial Maximum from sea-level observations and glacial-rebound models, Quan. Sci. Rev., 23, 1053-1077, doi:10.1016/j. quascirev.2003.11.001.

Forsberg, R., and C. C. Tscherning (2008), An overview manual for the GRAVSOFT, Geodetic Gravity Field Modelling Programs, 2.edition August 2008, Niels Bohr Institute, University of Copenhagen.

Howat, I. M., I. Joughin, and T. A. Scambos (2007), Rapid Changes in Ice Discharge from Greenland Outlet Glaciers, Science, 315(1559), doi: $10.1126 /$ science. 1138478 .

Howat, I. M., B. E. Smith, I. Joughin, and T. A. Scambos (2008), Rates of southeast Greenland ice volume loss from combined ICESat and ASTER observations, Geophys. Res. Lett., 35, L17505, doi:10.1029/ 2008 GL034496.

Hurkmans, R. T. W. L., J. L. Bamber, L. S. Sørensen, I. R. Joughin, C. H. Davis, and W. B. Krabill (2012), Spatiotemporal interpolation of elevation changes derived from satellite altimetry for Jakobshavn Isbræ, Greenland, J. Geophys. Res., 117, F03001, doi:10.1029/2011JF002072.

Jacob, T., J. Wahr, W. T. Pfeffer, and S. Swenson (2012), Recent contributions of glaciers and ice caps to sea level rise, Nature, 482, doi:10.1038/ nature 10847.

Johansson, J. M., et al. (2002), Continuous GPS measurements of postglacial adjustment in Fennoscandia 1. Geodetic results, J. Geophys. Res., 107(B8), 2157, doi:10.1029/2001JB000400.

Joughin, I., B. Smith, I. M. Howat, T. Scambos, and T. Moon (2010), Greenland Flow Variability from Ice-Sheet-Wide Velocity Mapping, J. Glacio., 56(197), 415-430, doi:10.3189/002214310792447734.

Khan, S. A., J. Wahr, L. A. Stearns, G. S. Hamilton, T. van Dam, K. M. Larson, and O. Francis (2007), Elastic uplift in southeast Greenland due to rapid ice mass loss, Geophys. Res. Lett., 34, L21701, doi:10.1029/ 2007GL031468.

Khan, S. A., J. Wahr, E. Leuliette, T. van Dam, K. M. Larson, and O. Francis (2008), Geodetic measurements of postglacial adjustments in Greenland, J. Geophys. Res., 113, B02402, doi:10.1029/2007JB004956.

Khan, S. A., J. Wahr, M. Bevis, I. Velicogna, and E. Kendrick (2010a), The spread of ice mass loss into northwest Greenland observed by GRACE and GPS, Geophys. Res. Lett., 37, L06501, doi:10.1029/2010GL042460.

Khan, S. A., L. Liu, J. Wahr, I. Howat, I. Joughin, T. van Dam, and K. Fleming (2010b), GPS measurements of crustal uplift near Jakobshavn Isbræ due to glacial ice mass loss, J. Geophys. Res., 115, B09405, doi:10.1029/2010JB007490.

King, M. A., et al. (2010), Improved Constraints on Models of Glacial Isostatic Adjustment: A Review of the Contribution of Ground-based Geodetic Observations, Surv. Geophys., 31, 465-507, doi:10.1007/ s10712-010-9100-4.

Kjær, K. H., et al. (2012), Aerial Photographs Reveal Late-20th-Century Dynamic Ice Loss in Northwestern Greenland, Science, 337(569), doi:10.1126/science. 1220614 .

Krabill, W. B., W. Abdalati, E. B. Frederick, S. S. Manizade, C. F. Martin, J. G. Sonntag, R. N. Swift, R. H. Thomas, and J. G. Yungel (2002), Aircraft laser altimetry measurement of elevation changes of the
Greenland ice sheet: technique and accuracyassessment, J. Geodyn., 34, 357-376, doi:10.1016/S0264-3707(02)00040-6.

Krabill, W. B. (2011), IceBridge ATM L2 Icessn Elevation, Slope, and Roughness, [1994-2010]. Boulder, Colorado USA: National Snow and Ice Data Center. Digital media.

Larsen, C. F., R. J. Motyka, J. T. Freymueller, K A. Echelmeyer, and E. R. Ivins (2005), Rapid viscoelastic uplift in southeast Alaska caused by post Little Ice Age glacial retreat, Earth Planet. Sci. Lett., 237, 548-560, doi:10.1016/j.eps1.2005.06.032.

Liu, L, J. Wahr, I. Howat, S. A. Khan, I. Joughin, and M. Furuya (2012), Constraining ice mass loss from Jakobshavn Isbræ (Greenland) using InSAR-measured crustal uplift, Geophys. J. Int., 188(3), 994-1006, doi:10.1111/j.1365-246X.2011.05317.x.

Luthcke, S. B., H. J. Zwally, W. Abdalati, D. D. Rowlands, R. D. Ray, R. S. Nerem, F. G. Lemoine, J. J. McCarthy, and D. S. Chinn (2006), Recent Greenland ice mass loss by drainage system from satellite gravity observations, Science, 314(5803), 1286-1289, doi:10.1126/science.1130776.

Nielsen, K., S. A. Khan, N. J. Korsgaard, K. H. Kjær, J. Wahr, M. Bevis, L. Stearns, and L. H. Timm (2012), Recent changes on Upernavik Isstrøm, West Greenland, Earth Planet. Sci. Lett., 353-354, 182-189, doi:10.1016/ j.epsl.2012.08.024.

NSIDC (2010), http://nsidc.org/data/icesat/detailed disclaimer. html \# SatCorrNote.

Peltier, W. R. (2004), Global glacial isostasy and the surface of the ice-age Earth: the ICE-5 G (VM2) model and GRACE, Annu. Rev. Earth Planet. Sci., 32, 111-149, doi:10.1146/annurev.earth.32.082503.144359.

Pritchard, H. D., R. J. Arthern, D. G. Vaughan, and L. A. Edwards (2009), Extensive dynamic thinning on the margins of the Greenland and Antarctic ice sheets, Nat. Geosci., doi:10.1038/nature08471.

Petrov, L., and J.-P. Boy (2004), Study of the atmospheric pressure loading signal in VLBI observations, J. Geophys. Res., 109, B03405, doi:10.1029/2003JB002500.

Reeh, N. (1991), Parameterization of melt rate and surface temperature on the Greenland Ice Sheet, Polarforschung, 59(3), 113-128.

Reeh, N., D. A. Fisher, R. M. Koerner, and H. B. Clausen (2005), An empirical firn-densification model comprising ice lenses, Ann. Glaciol., 42, 101-106, doi:10.3189/172756405781812871.

Reeh, N. (2008), A nonsteady-state firn-densication model for the percolation zone of a glacier, J. Geophys. Res., 113, F03023, doi:10.1029/ 2007JF000746.

Rignot, E., J. E. Box, E. Burgess, and E. Hanna (2008), Mass balance of the Greenland ice sheet from 1958 to 2007, Geophys. Res. Lett., 35, L20502, doi:10.1029/2008GL035417.

Rignot, E., I. Velicogna, M. R. van den Broeke, A. Monaghan, and J. Lenaerts (2011), Acceleration of the contribution of the Greenland and Antarctic ice sheets to sea level rise, Geophys. Res. Lett., 38, L05503, doi:10.1029/2011GL046583.

Sasgen, I, M. van den Broeke, J. L. Bamber, E. Rignot, L. S. Sørensen, B. Wouters, Z. Martinec, I. Velicogna, and S. B. Simonsen (2012), Timing and origin of recent regional ice-mass loss in Greenland, Earth Planet, Sci. Lett., 333-334, 293-303, doi:10.1016/j.eps1.2012.03.033.

Simpson, M. J. R., G. A. Milne, P. Huybrechts, and A. J. Long (2009), Calibrating a glaciological model of the Greenland ice sheet from the Last Glacial Maximum to present-day using field observations of relative sea level and ice extent, Qua. Sci. Rev., 28, 1631-1657, doi:10.1016/ j.quascirev.2009.03.004.

Simpson, M. J. R., L. Wake, G. A. Milne, and P. Huybrechts (2011), The influence of decadal- to millennial-scale ice mass changes on present-day vertical land motion in Greenland: Implications for the interpretation of GPS observations, J. Geophys. Res., 116, B02406, doi:10.1029/ 2010JB007776.

Smith, B. E., H. A. Fricker, I. R. Joughin, and S. Tulaczyk (2009), An inventory of active subglacial lakes in Antarctica detected by ICESat (20032008), J. Glaciol., 55, L21S09, doi:10.3189/002214309789470879.

Spada, G., G. Ruggieri, L. S. Sørensen, K. Nielsen, D. Melini, and F. Colleoni (2012), Greenland uplift and regional sea level changes from ICESat observations and GIA modelling, Geophys. J. Int., 189(3), 1457-1474, doi:10.1111/j.1365-246X.2012.05443.x.

Stearns, L. A., and G. S. Hamilton (2007), Rapid volume loss from East Greenland outlet glaciers quantified using repeat stereo satellite imagery, Geophys. Res. Lett., 34, L05503, doi:10.1029/2006GL028982.

Thomas, R., E. Frederick, W. Krabill, S. Manizade, and C. Martin (2006), Progressive increase in ice loss from Greenland, Geophys. Res. Lett., 33, L10503, doi:10.1029/2006GL026075.

Van Angelen, J. H., J. T. M. Lenaerts, S. Lhermitte, X. Fettweis, P. Kuipers Munneke, M. R. van den Broeke, E. van Meijgaard, and C. J. P. P. Smeets (2012), Sensitivity of Greenland Ice Sheet surface mass balance to surface albedo parameterization: a study with a regional climate model, Cryosphere, 6, 1175-1186, doi:10.5194/tc-6-1175-2012. 


\section{KJELDSEN ET AL.: IMPROVING ICE VOLUME LOSS}

van den Broeke, M., J. Bamber, J. Ettema, E. Rignot, E. Schrama, W. J. v. d. Berg, E. v. Meijgaard, I. Velicogna, and B. Wouters (2009), Partitioning Recent Greenland Mass Loss, Science, 326(984), doi:10.1126/science. 1178176.

Velicogna, I., and J. Wahr (2006), Acceleration of Greenland ice mass loss in spring 2004, Nature, 433, 329-331, doi:10.1038/nature05168.

Velicogna, I. (2009), Increasing rates of ice mass loss from the Greenland and Antarctic ice sheets revealed by GRACE, Geophys. Res. Lett., 36, L19503, doi:10.1029/2009GL040222.

Wahr, J., M. Molenaar, and F. Bryan (1998), Time variability of the Earth's gravity field: Hydrological and oceanic effects and their possible detection using GRACE, J. Geophys. Res., 103(B12), 30,205-30,229, doi:10.1029/ 98JB02844.

Wahr, J., T. van Dam, K. Larson, and O. Francis (2001), Geodetic measurements in Greenland and their implications, J. Geophys. Res., 106(B8), $16,567-16,581$
Wouters, B., D. Chambers, and E. J. O. Schrama (2008), GRACE observes small-scale mass loss in Greenland, Geophys. Res. Lett., 35, L20501, doi:10.1029/2008GL034816.

Zwally, H. J., et al. (2002), ICESAT's laser measurements of polar ice, atmosphere, ocean, and land, J. Geodyn., 34, 405-445.

Zwally, J. H., and L. Jun (2002), Seasonal and Interannual Variations of Ice Sheet Surface Elevation at the Summit of Greenland: Observed and Modeled, J. Glac., 48(161), 199-207, doi:10.3189/ 172756502781831403.

Zwally, H. J., M. B. Giovinetto, J. Li, H. G. Cornejo, M. A. Beckley, A. C. Brenner, J. L. Saba, and D. Yi (2005), Mass changes of the Greenland and Antarctic ice sheets and shelves and contributions to sea-level rise: 1992 2002, J. Glacio., 51(175), 509-527, doi:10.3189/172756505781829007.

Zwally, H. J., R. Schutz, C. Bentley, J. Bufton, T. Herring, J. Minster, J. Spinhirne, and R. Thomas (2011), GLAS/ICESat L2 Antarctic and Greenland Ice Sheet Altimetry Data V031. Boulder, CO: National Snow and Ice Data Center. Digital media. 